Creative Commons User License: CC BY-NC-ND

Abstracted by: EBSCOhost, Electronic Journals Service (EJS),

Google Scholar, Journal Seek, Scientific Commons,

Food and Agricultural Organization (FAO), CABI and Scopus
Journal of Agricultural Extension

Vol. 25 (2) April, 2021

ISSN(e): 24086851; ISSN(Print); 1119944X

http://journal.aesonnigeria.org

http://www.ajol.info/index.php/iae

Email: editorinchief@aesonnigeria.org

http://eoi.citefactor.org/10.11226/v25i2

\title{
Soil Chemical Properties and Yield Response of Okra (Abelmoschus Esculentus L) to Different Organic Fertilizer Sources
}

https://dx.doi.org/10.4314/jae.v25i2.6

\section{Unagwu, Benedict. 0.}

Department of Soil Science, University of Nigeria, Nsukka, Nigeria

Email: benedictunagwu@unn.edu.ng Phone:08039520118

\section{Ayogu, Roseline. U.}

Department of Soil Science, University of Nigeria, Nsukka, Nigeria

Email: rose.amaka2015@gmail.com Phone: 08066622493

\section{Osadebe, Vivian.O}

Department of Crop Science, University of Nigeria, Nsukka, Nigeria

Email: vivian.ugwuaneke@unn.edu.ng Phone: 08064535517

*Corresponding author: vivian.ugwuaneke@unn.edu.ng

\section{Abstract}

The study investigated the effects of animal manures (cow manure, CoM; chicken droppings, CkD; and pig manure, PiM) applied at $15 t_{\text {ha }}^{-1}$ equivalent rate on the soil and growth performance of okra grown in a degraded ultisol. The treatments (CoM; CoM; PiM and Control unamended) were laid out in a completely randomized design and replicated three times. Animal manure application had significant effects on soil properties. Soilorganic matter increased by over $9 \%$ in the amended treatment relative to the control treatment. Except for $N$, increases in $P$ (circa 14-70\%)and $K$ (circa 15-46\%) nutrients were higher for CkD treatment than in other treatments. Generally, the amended treatments maintained a significantly higher $(p \leq 0.05)$ plant leave number, stem girth, plant height, okra pod length and yields when compared with the Control treatment. The results indicated that application of animal manure enhanced okra growth performance. The findings suggest that animal manure application can potentially increase okra yield when grown in a degraded soil. It is recommended that farmers use ample (15 t ha $\left.{ }^{-1)}\right)$ quantity of animal manures to increase their crop yields, which invariably will enhance their income.

Keywords: Soil fertility, organic fertilizers okra growth, okra yield response, farmers okra yeild.

\section{Introduction}

One of the important vegetables cultivated, especially in the tropics and subtropics, for its edible green fruit which can either be eaten either raw or cooked, is okra (Abelmoschus esculentus L.). Okra plays a critical role in tropical diet because the soft immature pods contain a glutinous sticky substance that is used as soup thickener. It is a good source of vitamins and minerals and it also contains 
Creative Commons User License: CC BY-NC-ND

Abstracted by: EBSCOhost, Electronic Journals Service (EJS), Google Scholar, Journal Seek, Scientific Commons,

Food and Agricultural Organization (FAO), CABI and Scopus

http://eoi.citefactor.org/10.11226/v25i2
Journal of Agricultural Extension

Vol. 25 (2) April, 2021

ISSN(e): 24086851; ISSN(Print); 1119944X

http://journal.aesonnigeria.org

http://www.ajol.info/index.php/iae

Email: editorinchief@aesonnigeria.org

substantial amount of protein, carbohydrate and fat (Anisa, Markose, and Joseph, 2016). It is also rich in fibre content which can enhance food digestion. Okra leaves are medicinal and can be used as a curative medicine against ulcer and haemorrhage (Khetran, Kasi, Agha, Fahmud, and Ali, 2016).

One critical challenge facing okra production in the tropics, especially Nigeria, is poor soil health. This has been attributed to continuous cropping of a piece of land for food with inadequate care for the land with respect to external nutrient (organic or inorganic fertilizer) application (Unagwu, 2019). Undoubtably, inorganic fertilizers improve crop growth and yield performance. However, there are challenges associated with the use of inorganic fertilizers which makes continuous use or application of inorganic fertilizers unsustainable. Some of these challenges include: high procurement cost, scarcity, nitrogen nutrient loss through volatilization, high soil acidity with constant inorganic fertilizer application (Olujugba, Sayo, Anuoluwapo, and Anuoluwapo2016). Persistence use of inorganic fertilizer has a lasting negative effect on soil properties and soil fertility statusdue to its effect on soil nutrient balance (Unagwu, 2019).

With the challenges associated with inorganic fertilizer application, the use of organic manure to replenish soil nutrient appears a viable alternative. This is because organic manure improves plant nutrient use efficiency, enhances soil conditions by improving the physical, chemical, biological and hydrological properties of the soil (Olujugba et al., 2016; Unagwu, Simmons and Rickson (2019). Organic manure also improves crop yield and reduces the impact of soil degradation (Unagwu, 2019). Crop production with respect to fertilizer application can only be sustained if soil fertility is maintained at a level that marches the crop requirement (Mohammed, Aroifee, Fatemi, Atefe, and Karimpour., 2017). Despite the low soil fertility status, most farmers apply insufficient quantity of NPK fertilizer which is far below the recommended rate. This sort of agricultural practice can further deplete available soil nutrients and negatively affects crop yield performance. Study suggested that application of manure can improve soil fertility status, increase crop yield and farmer's income (Eifediyi, Mohammed, and Remison, 2015). However, to achieve increased crop yield following manure application, it is necessary to apply adequate quantity of the manure (Akintomide and Osundare,2015). To feed the overly growing population, efficient soil management and good agricultural practices are critically essential. This is because crop production is largely dependent on soil health, and proper soil nutrient management are critical to achieving sustainable crop production. Thus, this study evaluated the effectsof application of organic (animal) manure on soil properties and growth and yield of okra.

\section{Methodology}

A study was set up in a complete randomized design (CRD) with three replications to evaluate the effects of animal manure application on soil properties and growth performance of okra. A $0-15 \mathrm{~cm}$ test soil was collected from the Department of Soil Science Research Farm, University of Nigeria, Nsukka. The animal manures (cow manure, CoM,chicken manure, $\mathrm{CkD}$, and pig manure, PiM) were gotten from the Faculty of Agriculture Research Farm, UNN. The study treatments were: CkD applied 
Creative Commons User License: CC BY-NC-ND

Abstracted by: EBSCOhost, Electronic Journals Service (EJS),

Google Scholar, Journal Seek, Scientific Commons,

Food and Agricultural Organization (FAO), CABI and Scopus

http://eoi.citefactor.org/10.11226/v25i2
Journal of Agricultural Extension

Vol. 25 (2) April, 2021

ISSN(e): 24086851; ISSN(Print); 1119944X

http://journal.aesonnigeria.org

http://www.ajol.info/index.php/iae

Email: editorinchief@aesonnigeria.org

at $15 \mathrm{t} \mathrm{ha}^{-1}$; CoM applied at $15 \mathrm{tha}^{-1}$; PiM applied at $15 \mathrm{tha}^{-1}$; and the Control, with no amendment application. A $10 \mathrm{~kg}$ air-driedtest soil sample was weighed out into a pot containing a pre-weighed animal manure type and was thoroughly mixed to ensure uniformity of the treatments. After application, the treatments were watered for twoweeks, thereafter three okra seeds (Clemson spineless variety) were planted per pot and was reduced to one seedling per treatment pot, after seedling emergence.

The following instruments were used to obtain data on okra plant at two-week intervalsfor a 12-weekperiod, after seed emergence. A measuring tape calibrated in centimeter $(\mathrm{cm})$ was used to obtain the heights of okraplant which was taken from the stem base up to the plant tip. Data on pod length was obtained by measuring (in $\mathrm{cm}$ ) from the base of the pod to its tip. The number of plant leaves and number of okra pods produced was manually obtained by counting.

\section{Soil sample analysis}

Before treatment application and at the end of the study, soil samples (about $100 \mathrm{~g}$ ) were taken for chemical analysis. $\mathrm{pH}$ meter was used to obtain soil pH in a soil: liquid ratio of 1:2.5 suspensions of soil in $0.1 \mathrm{~N} \mathrm{KCl}$ and distilled water. Organic carbon wasdetermined bythe Walkley-Black Method (Nelson and Somners 1996) and thereafter multiplied by1.724 (a conversion factor) to obtain soil organic matter. Exchangeable potassium was extracted using $1 \mathrm{M}$ ammonium acetate, then read on a flame photometer (Thomas, 1982). Phosphorus was determined usingthe Bray II Method (Bray and Kurtz, 1945) while total nitrogen was by the Macro KjeldahlMethod (Bremner, 1996). The animal manures were also analysed following the abovementioned procedures.

\section{Statistical analysis}

One-way Analysis of Variance (ANOVA) was applied on the parameters measured using GENSTAT Software Statistical tool. The least significant difference (LSD) was used to separate the mean differences of the soil and plant attributesat $5 \%$ probability level.

\section{Results and Discussion}

\section{Chemical Properties of Animal Manures and Initial Test Soil Sample}

Prior to treatment application, the $\mathrm{pH}$ of the test soil was moderately acidic and has low Organic matter (OM), N, P and K contents (Table 1). This indicate that the test soil has low soil nutrient which willconsequently affect farmers' yield and income. However, the animal manures (Table 1) are associated with huge nutrients. This suggests that animal manure application which are rich in NPK and OM contents will enhance the test soil fertility status and consequently improve farmers' crop yields. 
Creative Commons User License: CC BY-NC-ND

Abstracted by: EBSCOhost, Electronic Journals Service (EJS),

Google Scholar, Journal Seek, Scientific Commons,

Food and Agricultural Organization (FAO), CABI and Scopus

http://eoi.citefactor.org/10.11226/v25i2
Journal of Agricultural Extension

Vol. 25 (2) April, 2021

ISSN(e): 24086851; ISSN(Print); 1119944X

http://journal.aesonnigeria.org

http://www.ajol.info/index.php/iae

Email: editorinchief@aesonnigeria.org

Table 1: Chemical properties of animal manures and initial soil sample used in the study

\begin{tabular}{lccc|cc}
\hline Parameters & Units & \multicolumn{3}{c}{ Organic amendments } & Soil sample \\
\cline { 3 - 4 } & & $\begin{array}{c}\text { Cow } \\
\text { Manure }\end{array}$ & $\begin{array}{c}\text { Pig } \\
\text { Manure }\end{array}$ & $\begin{array}{c}\text { Chicken } \\
\text { Droppings }\end{array}$ & \\
\hline $\mathrm{pH}\left(\mathrm{H}_{2} \mathrm{O}\right)$ & & 7.1 & 6.6 & 8.3 & 5.4 \\
$\mathrm{pH}(\mathrm{KCl})$ & 6.1 & 5.9 & 8.0 & 4.7 \\
Total N & $\left(\mathrm{mg} \mathrm{kg}^{-1}\right)$ & 1920 & 3180 & 1800 & 5.15 \\
Total P & $\left(\mathrm{mg} \mathrm{kg}^{-1}\right)$ & 210 & 420 & 576 & 7.90 \\
Available $\mathrm{K}$ & $\left(\mathrm{mg} \mathrm{kg}^{-1}\right)$ & 151 & 250 & 265 & 5.95 \\
Organic & $(\%)$ & 22.9 & 50.4 & 56.5 & 1.41 \\
matter & & & & \\
\hline
\end{tabular}

\section{Treatment Effect on Soil Properties14 Weeks after Application}

Treatments had positive $(p \leq 0.05)$ effect on the soil chemical properties 14 weeks after application (Table 2).CkD Treatment had the highest $(p \leq 0.05 ; 7.8) \mathrm{pH}$ value while the Control treatment, recorded the least $(\mathrm{p}<0.05 ; 5.0) \mathrm{pH}$ value. CoM and PiM treatments did not differ significantly on their soil pH content. The high soil $\mathrm{pH}$ values associated with the animal manure amended treatments attests to the capability of animal manures in enriching the soil and improving the acidic conditions. The result obtained is similar to a studybyUnagwu, Simmons and Rickson (2019) who reported increases in soil $\mathrm{pH}$ following application of manure. As anticipated, the total $\mathrm{N}$ content in the Control treatment was significantly lower as compared with treatments CkD, CoM and PiMTreatments. The high ( $\left.p \leq 0.05 ; 23.8 \mathrm{mg} \mathrm{kg}^{-1}\right)$ total $\mathrm{N}$ content in PiMTreatment relative to $\mathrm{CkD}$ and CoMTreatments is due to the high $\mathrm{N}$ level that is associated with pig manure prior to its application (Table 1).

CkD, CoM and PiMTreatmentshad significantly higher $\mathrm{P}$ content as with compared with of Control treatment. There was over $35 \%$ increase in soil $P$ content following animal manure application relative to the Control treatment (Table 2). The data on soil organic matter $(\mathrm{OM})$ showed that the amended treatments had higher $(p \leq 0.05)$ OM content relative to the Control treatment which had the least OM content while CkD treatment had the highestOM content. In a study by Are, Adelana, Fademi, and Aina(2017), they reported about 1.6-2.1 folds increase in soil organic carbon following organic amendment application. As anticipated, this study indicate that animal manure application improves the soil nutrient content, which consequently will improve farmers' crop output. 
Creative Commons User License: CC BY-NC-ND

Abstracted by: EBSCOhost, Electronic Journals Service (EJS),

Google Scholar, Journal Seek, Scientific Commons,

Food and Agricultural Organization (FAO), CABI and Scopus

http://eoi.citefactor.org/10.11226/v25i2
Journal of Agricultural Extension

Vol. 25 (2) April, 2021

ISSN(e): 24086851; ISSN(Print); 1119944X

http://journal.aesonnigeria.org

http://www.ajol.info/index.php/iae

Email: editorinchief@aesonnigeria.org

Table 2: Treatment effect on soil chemical properties 14 weeks after application

\begin{tabular}{lcccccc}
\hline Treatments & Units & CkD & CoM & PiM & Control & LSD \\
\hline $\mathrm{pH}\left(\mathrm{H}_{2} \mathrm{O}\right)$ & - & 7.8 & 6.5 & 6.3 & 2.0 & 0.30 \\
Total N & $\left(\mathrm{mg} \mathrm{kg}^{-1}\right)$ & 13.7 & 16.6 & 22.8 & 0.55 & 3.01 \\
Total P & $\left(\mathrm{mg} \mathrm{kg}^{-1}\right)$ & 38.4 & 9.3 & 19.3 & 6.04 & 2.41 \\
Available $\mathrm{K}$ & $\left(\mathrm{mg} \mathrm{kg}^{-1}\right)$ & 9.16 & 6.39 & 6.74 & 5.20 & 1.12 \\
Organic & $(\%)$ & 1.39 & 1.27 & 1.41 & 1.19 & 0.06 \\
matter & & & & & &
\end{tabular}

CkD, 15 t ha-1Chickendroppings; CoM, $15 \mathrm{t} \mathrm{ha}^{-1}$ Cow manure; PiM, $15 \mathrm{t} \mathrm{ha}^{-1}$ Pig manure; manure application, CV, Coefficient of variation, LSD, Least significant difference

\section{Treatment Effect on Stem Girth, Number of Plant Leaves Produced and Plant Height}

There were significant but varied effects on okra growth parametersfollowing treatment application. No significant effects on the stem girth was observed across the treatments 28 days after sowing (DAS)(Table 3). But, from 42 DAS and beyond, CkD, CoMand PiMtreatments recorded significant $(p \leq 0.05)$ wider stem girth relative to the Control treatment (Table 4). Throughout the plant growth period, animal manured treatments had taller $(16-60.4 \mathrm{~cm})$ plant heightsas compared with the shortest $(14-37 \mathrm{~cm})$ plant height that was recorded for the control treatment (Table 3). $\mathrm{CkD}$ treatment consistently maintained taller plant heights relative to all other treatments. The number of plant leaves (NPL) produced varied significantly across the treatments(Table 3 ). CkD and PiM treatments consistently had significantly higher NPL relative to theControl treatment. However, both (CkDand PiM)treatments did not significantly vary in their NPL produced except at 70 DAS in which the NPL in $\mathrm{CkD}$ treatment was significantly higher than PiM treatment.

The result of this study is similar to the findings of Akintomide and Osundare (2015) who recorded increases $(p \leq 0.05)$ in okra stem girth when compost organic fertilizer was applied relative to the control treatment. The taller plant heights associated with CkD treatment can be attributed to the high $\mathrm{P}$ nutrient contents that is contained in the chicken manure applied (Table 1). This is because $\mathrm{P}$ nutrient is a critical nutrient required for cell division that results in increase in plant growth (Khandaker, 2017). The results on NPL are supported by similar study by Anisa, Markose, and Joseph (2016)who reported higher number of okra leaves when manurewas applied relative to the control unamended treatment. Similarly, Khandaker, Fadhilah, Dalorima, Sajili and Mat (2017)reported that poultry manure application increased the number of okra leaves by $37.8 \%$ as compared with theControl treatment. 
Creative Commons User License: CC BY-NC-ND

Abstracted by: EBSCOhost, Electronic Journals Service (EJS),

Google Scholar, Journal Seek, Scientific Commons,

Food and Agricultural Organization (FAO), CABI and Scopus

http://eoi.citefactor.org/10.11226/v25i2
Journal of Agricultural Extension

Vol. 25 (2) April, 2021

ISSN(e): 24086851; ISSN(Print); 1119944X

http://journal.aesonnigeria.org

http://www.ajol.info/index.php/jae

Email: editorinchief@aesonnigeria.org

Table 3: Effect of manure application on okra stem girth, number of plant leaves and plant height

\begin{tabular}{|c|c|c|c|c|c|c|}
\hline Treatments & 14DAS & 28DAS & 42DAS & 56DAS & 70 DAS & 84DAS \\
\hline \multicolumn{7}{|c|}{ Stem girth $(\mathrm{cm})$} \\
\hline CkD & 1.0 & 1.3 & 2.3 & 2.6 & 3.0 & 3.2 \\
\hline CoM & 0.9 & 1.2 & 2.0 & 2.5 & 2.7 & 2.8 \\
\hline PiM & 1.0 & 1.4 & 2.1 & 2.6 & 2.9 & 3.2 \\
\hline Control & 0.8 & 1.0 & 1.6 & 2.0 & 2.0 & 2.1 \\
\hline $\mathrm{CV}$ & 7.4 & 8.9 & 8.3 & 10.1 & 7.8 & 5.3 \\
\hline LSD & NS & 0.2 & 0.3 & 0.25 & 0.35 & 0.4 \\
\hline \multicolumn{7}{|c|}{ Plant height $(\mathrm{cm})$} \\
\hline CkD & 18.0 & 28.3 & 43.5 & 52.0 & 57.3 & 60.4 \\
\hline CoM & 16.0 & 25.3 & 36.7 & 45.5 & 46.7 & 48.0 \\
\hline PiM & 17.0 & 24.0 & 36.3 & 46.7 & 48.7 & 51.7 \\
\hline Control & 14.0 & 21.5 & 25.0 & 32.0 & 36.3 & 37.0 \\
\hline $\mathrm{CV}$ & 5.50 & 7.6 & 8.30 & 9.4 & 11.9 & 13.1 \\
\hline LSD & 1.03 & 3.3 & 4.8 & 5.2 & 6.4 & 8.4 \\
\hline \multicolumn{7}{|c|}{ Number of plant leaves } \\
\hline CkD & 3.50 & 4.0 & 5.3 & 6.6 & 8.3 & 9.87 \\
\hline CoM & 3.60 & 4.6 & 5.0 & 5.5 & 5.6 & 8.30 \\
\hline PiM & 3.10 & 3.6 & 5.4 & 6.7 & 6.5 & 9.47 \\
\hline Control & 2.40 & 2.6 & 3.4 & 4.5 & 5.2 & 4.40 \\
\hline $\mathrm{CV}$ & 5.50 & 6.6 & 7.45 & 7.9 & 8.9 & 9.13 \\
\hline LSD & 0.10 & 0.73 & 1.18 & 1.12 & 1.4 & 1.2 \\
\hline
\end{tabular}

CkD, $15 \mathrm{t}^{-1} \mathrm{C}^{-1}$ Chicken droppings; CoM, $15 \mathrm{t} \mathrm{ha}^{-1}$ Cow manure; PiM, $15 \mathrm{t} \mathrm{ha}^{-1}$ Pig manure; manure application, DAS, Day after sowing; CV, Coefficient of variation, LSD, Least significant difference 
Creative Commons User License: CC BY-NC-ND

Abstracted by: EBSCOhost, Electronic Journals Service (EJS),

Google Scholar, Journal Seek, Scientific Commons,

Food and Agricultural Organization (FAO), CABI and Scopus
Journal of Agricultural Extension

Vol. 25 (2) April, 2021

ISSN(e): 24086851; ISSN(Print); 1119944X

http://journal.aesonnigeria.org

http://www.ajol.info/index.php/iae

Email: editorinchief@aesonnigeria.org

http://eoi.citefactor.org/10.11226/v25i2

\section{Treatment Effect on other Plant Parameters and Okra Yield}

The Controltreatment had significantly longer days to flowering as compared with CkD, CoM and PiM treatments (Table 4). The treatment effects on the days to flowering of okra is as follows: Control $>\mathrm{PiM}>\mathrm{CkD}>\mathrm{CoM}$. It is not entirely clear why CoM treatment had the lest days (period) to flowering of okra. However, the longer days toflowering associated with the Control treatment is linked to low or insufficient nutrient provisioning resulting in the prolonged days toflowering. This is evidenced by the significant $(p \leq 0.05)$ negative correction between soil nutrients $(P$ and $K)$ and days to flowering. This suggests that soil nutrient availability can influence okra flowering initiation and consequently affect okra yield. The amended treatments (CkD, CoM and PiM) had higher $(p \leq 0.05)$ number of pods produced relative to the Control treatment. No significant difference in the number of pods produced was observed between CkD and PiM (Table 4). A similar trend in the number of pods produced was observed for the okra pod length (Table 4).

PiM treatment had weightiest (12.2 gplant $\left.^{-1}, \mathrm{p} \leq 0.05\right)$ pod yield compared with all other treatments except $\mathrm{CkD}$ treatment both of which were statistically the same, while the Control treatment had lest yield (5.36 gplant $\left.{ }^{-1}\right)$. The poor crop performance associated with the Control treatment relative to the animal manured treatments is due to inadequate soil nutrient supply. This is because fertilizers are important soil inputs needed to enhance not only crop yield, but they also improve the quantity and quality of crop yields (Molik, Eluwa, Oluwatobi, Lakwannum and Olorunmaiye, 2016). This is further supported by the significant $(p \leq 0.05)$ positive correlation between soil nutrients and okra pod yield (Table 5).

Soil $\mathrm{K}$ nutrientis essential for increased fruit size and crop yields. This is because $\mathrm{K}$ contributesto plant photophosphorylation, enzyme activation, and transportation of photo-assimilates from source tissues via the phloem to sink tissues nutrients (Soremi, Adetunji, Adejuyigbe, Bodunde, and Azeez (2017). In a similar study, Usman (2015) reported that poultry manure, goat manure and cow manure applied at $20 \mathrm{t} \mathrm{ha}^{-1}$ increased tomato yield relative to the control treatment. Molik, Eluwa, Oluwatobi, Lakwannum and Olorunmaiye (2016) reported higher yield with manure treatment application relative to the control treatment which had the least yield. Overall, as anticipated, there are significant increases in okra yield parametersanimal manures relative to the unamended control. This implies that farmers that apply adequate amount of animal manures will have higher crop yield as compared with when little or no animal manures were applied. 
Creative Commons User License: CC BY-NC-ND

Abstracted by: EBSCOhost, Electronic Journals Service (EJS),

Google Scholar, Journal Seek, Scientific Commons,

Food and Agricultural Organization (FAO), CABI and Scopus

http://eoi.citefactor.org/10.11226/v25i2
Journal of Agricultural Extension

Vol. 25 (2) April, 2021

ISSN(e): 24086851; ISSN(Print); 1119944X

http://journal.aesonnigeria.org

http://www.ajol.info/index.php/iae

Email: editorinchief@aesonnigeria.org

Table 4: Effect of manure application on reproductive and yield performance

\begin{tabular}{lcccccc}
\hline Treatments & CkD & CoM & PiM & Control & CV & LSD \\
\hline Days to flowering & 39.5 & 37.2 & 43.1 & 48.0 & 10.7 & 2.5 \\
Number of pod & 2.1 & 1.8 & 2.5 & 1.0 & 11.4 & 0.6 \\
Pod length (cm) & 9.2 & 7.0 & 9.3 & 6.6 & 3.1 & 1.1 \\
Pod yield (g plant & 11.0 & 7.87 & 12.4 & 5.36 & 11.2 & 1.11 \\
1) & & & & & \\
\hline
\end{tabular}

CkD, $15 \mathrm{t}$ ha-1Chickendroppings; CoM, $15 \mathrm{tha}^{-1}$ Cow manure; PiM, $15 \mathrm{t} \mathrm{ha}^{-1}$ Pig manure; manure application, DAS, Day after sowing;CV, Coefficient of variation, LSD, Least significant difference

Table 5: Correlation between soil properties and okra growth and yield performance

\begin{tabular}{|c|c|c|c|c|c|c|}
\hline $\begin{array}{c}\text { Soil } \\
\text { Properties }\end{array}$ & $\begin{array}{l}\text { Days to } \\
\text { flowering }\end{array}$ & $\begin{array}{c}\text { Number } \\
\text { of } \\
\text { leaves }\end{array}$ & $\begin{array}{c}\text { Plant } \\
\text { height }\end{array}$ & $\begin{array}{l}\text { Pod } \\
\text { length } \\
\text { (cm) }\end{array}$ & $\begin{array}{l}\text { Number } \\
\text { of pods }\end{array}$ & $\begin{array}{c}\text { Pod } \\
\text { yield }(\mathrm{g})\end{array}$ \\
\hline Nitrogen & $-0.24^{\mathrm{ns}}$ & $0.67 \dagger$ & $0.59 \dagger$ & $0.65 \dagger$ & $0.64 \dagger$ & $0.67 \dagger$ \\
\hline Phosphorus & $-0.38 \dagger$ & $0.58 \dagger$ & $0.76 \dagger \dagger$ & $0.56 \dagger$ & $0.56 \dagger$ & $0.56 \dagger$ \\
\hline $\begin{array}{l}\text { Potassium } \\
\text { Organic }\end{array}$ & $-0.37 \dagger$ & $0.78+\dagger$ & $0.68 \dagger$ & $0.40 \dagger$ & $0.44 \dagger$ & $0.42 \dagger$ \\
\hline Matter & $-0.12^{\text {ns }}$ & $0.5 \dagger$ & $0.40 \dagger$ & $0.57 \dagger$ & $0.53 \dagger$ & $0.55 \dagger$ \\
\hline
\end{tabular}

\section{Conclusion and Recommendations}

Application of animal manure have positive affect on days to okraflowering, okra height, number of okra leaves produced, number of okra pods, pod yields. In addition, animal manure treatments had significant positive effects on soil nutrients (NPK) and organic matter content relative to the control treatment. Application of $15 \mathrm{t}$ ha $^{-1}$ poultry manure or pig manure to a nutrient-depleted soil can enhance okra growth, yield and soil chemical properties. Farmers should apply $15 \mathrm{t} \mathrm{ha}^{-1}$ of animal manures to improve the soil nutrient contents, enhance crop yieldperformance, which will consequently increase farmers' income.

\section{Reference}

Akintomide, T. A. and Osundare, B. (2015). Growth and yield responses of okra (Abelmoschus esculentus) and soil fertility status to NPK fertilizer application regime. International Journal of Research Studies in Agricultural Science, 1(3):11-16

Anisa, N. A., Markose, B. L and Joseph, S (2016). Effect of biofertilizer on yield attributing characters and yield of okra (Abelmoschus esculentus (L.) Moench). International Journal of Applied and Pure Science and Agriculture, 2(2):59-63

Are, K. S., Adelana, A O., Fademi, I. O., and Aina, O. A (2017). Improving physical properties of degraded soil: potential of poultry manure and biocher. Journal of Agricultural and Natural Science, 51:454-462. Doi.org/10.1016/j.anres.2018.03.009. 
Creative Commons User License: CC BY-NC-ND

Abstracted by: EBSCOhost, Electronic Journals Service (EJS),

Google Scholar, Journal Seek, Scientific Commons,

Food and Agricultural Organization (FAO), CABI and Scopus
Journal of Agricultural Extension

Vol. 25 (2) April, 2021

ISSN(e): 24086851; ISSN(Print); 1119944X

http://journal.aesonnigeria.org

http://www.ajol.info/index.php/iae

Email: editorinchief@aesonnigeria.org

http://eoi.citefactor.org/10.11226/v25i2

Bray, R. H.and Kurtz, N. T. (1945). Determination of total organic and available form of phosphorus in soil. Soil Science, 59: 39- 45.

Bremner, J. M. (1996). Nitrogen-total. P.1085-1121. In: D. L. Sparks (Ed). Methods of Soil Anaysis, Part III. Chemical methods. SSSA Book series No. 5. Am. Soc. of Agron. Madison, W. I.

Eifediyi, E. K., Mohammed, K. O. and Remison, S. U. (2015). Effect of neem (Azadirachta indica L.) seed cake on the growth and yield of okra (Abelmoschus esculentus $\mathrm{L}$. Moench). POLJOPRIVREDA, 21(1):46-52.

Khandaker, M. M., Fadhilah N. M., Dalorima, T., Sajili, M. H. Mat, N. (2017). Effect of different rates of inorganic fertilizer on physiology, growth and yield of okra (Abelmoschus esculentus) cultivated on BRIS soil of Terengganu, Malaysia. Australian Journal of Crop Science, 11(07):880-887 doi: 10.21475/ajcs.17.11.07.pne552.

Khetran, R. Kasi, M.A,Agha, S.A.H Fahmud, S and Ali, J (2016). Effect of different doses of NPK fertilizer on growth of okra (Abelmoschus esculentus (L) Moench). InternationalJournal of Advanced Research in Biological Science, 3 (10):213-218

Mohammed, H. A., Aroifee, H., Fatemi, H., Atefe, M. and Karimpour, S. (2017). Response of eggplant (solanum melongena L.) to different rates of nitrogen under field condition. Journal of Central European Agriculture,11(4):453-458.

Molik, A. Z., Eluwa, C. V.,Oluwatobi, S. A., Lakwannum, G. Y. and Olorunmaiye, S. K. (2016). Effect of organic and inorganic fertilizer on the growth of $\mathrm{NH}-\mathrm{Ae} 47-4$ variety of okra. Journal of Applied Science and Environmental Management, 20(1):201-206

Olujugba, M. R., Sayo, O.S., Anuoluwapo, R. O.andAnuoluwapo, O. (2016). Assessment of intergrated soil fertility management system on the growth and yield of Abelmoschus esculentus in a tropical alfisol. Scholars Journal of Agriculture and Veterinary Science, 3(3):212-218.

Soremi, A. O., Adetunji, M. T., Adejuyigbe, C.O., Bodunde,J. G and Azeez, J.O (2017). Influence of organic manure on phosphorus and potassium fraction on soil planted with soybean. International Journal of Plant and Soil Science, 14(2):1-11.

Thomas, G.W. (1982). Exchangeable cations. In: Page, A.L., Miller, R.H., Keeney D.R. (Eds.), Methods of soil analysis, 2nd edition, Part 2. American Society of Agronomy, Madison, WI, USA, pp. 159-165.

Unagwu, B. O. (2019). Organic amendment applied to a degraded soil: short term effect on soil quality indicators. African Journal of Agricultural Research, 14(4):218-225. Doi: 10.5897/AJAR2018.13457.

Unagwu, B. O., Simmons R. W. and Rickson J. R. (2019). Organic amendment and inorganic fertiliser addition: effect on soil nutrient, growth and yield of maize.Middle East Journal of Agriculture Research, 8(2): 13-25.

Usman, N. (2015). Cow dung, goat and poultry manure and their effect on the average yield and growth parameters of tomato crop. Journal of Biology, Agriculture and Healthcare, 5(5):7-11. 